\title{
REWOLUCJA I DIALEKTYKA - STO LAT PÓŹNIEJ
}

\author{
PRAK'TYKA 'TEORE'TYCZNA
}

Niniejszy numer Praktyki Teoretycanej zrodzil się z przekonania o konieczności ponownego przemyślenia związku dialektyki i rewolucji. Punkt wyjścia do tego namyslu stanowić moga dwa oddalone od siebie o blisko sto lat wydarzenia. Pierwsze z nich - rewolucja rosyjska, wraz ze swym październikowym przesileniem - inicjuje cykl walk społecznych przypadający na lata 1917-1976. Drugie jest wydarzeniem zupelnie innego rodzaju i kalibru. To śmierć Fidela Castro, chodzacego symbolu wspomnianego cyklu globalnych walk spolecznych, który przeżywszy go o kilka dekad, nawiedzał naszą postzimnowojenną rzeczywistość niczym komunistyczne zombie. Rewolucyjny przywódca Kuby wydawał się być coraz bardziej „,nie na miejscu", wciąż próbując stworzyć pod nosem Stanów Zjednoczonych (300 kilometrów od brzegów Florydy), rzeczywistą alternatywę dla kapitalizmu. Jakby przewrotny los rzucil go w inną epokę niż ta, do której prawdziwie przynależal. Teraz wraz z nim ze sceny dziejów znikać zdają się ostatnie pozostałości po nadziejach i rozczarowaniach dlugiego cyklu spolecznych zmagań, które czerpaly swą inspirację z rosyjskiej rewolucji.

Symboliczna śmierć Castro wydarzyła się niecałą dekade po jak najbardziej realnym kryzysie kapitalizmu, wyznaczającym kres kolejnej fazy akumulacji - fazy zglobalizowanego, zderegulowanego kapitalu, efektu konserwatywnej i neoliberalnej kontrrewolucji, która przeniosła zarządzanie reprodukcją stosunków ekonomicznych z poziomu państwowego na poziom globalny. Demontaż skoncentrowanego przemyslu i odpowiadającej mu formy 
państwa dobrobytu w krajach rozwiniętych postępowal wraz z przenoszeniem produkcji do krajów rozwijających się, gdzie przemoc kapitalistycznego wyzysku pozbawiona byla form regulacji wywalczonych przez klase robotnicza tzw. Zachodu. Rewolucja październikowa stanowila moment również tej historii: byla chwilą zwycięstwa klasy robotniczej w państwie spoza kapitalistycznego centrum, stając się na ponad pól wieku symbolem dla walk wymierzonych zarówno przeciwko kapitalistycznej, jak i imperialnej kontroli. W świecie, który zostal przeksztalcony przez zbuntowane podmiotowości robotnika i mieszkańca kolonii, faza kapitalistycznej globalizacji po kryzysach lat siedemdziesiatych XX wieku zaprowadziła nowy podzial pracy i nowy reżim globalnej produkcji. Obecna postać świata w stopniu znacznie większym niż przed stu lata domaga sie internacjonalizmu, nowej solidarności między pracującymi podmiotowościami.

Nie wiemy jeszcze, jaki będzie charakter nowych zbuntowanych podmiotowości rozpoczynającej sie właśnie fazy globalizacji, a tym samym nie wiemy też, jaka polityczną postać przyjmie międzynarodowa solidarność wyzyskiwanych i podporządkowanych. Uważamy, że jeśli chcemy zrozumieć dynamikę tej epoki i sens wypelniających ją doświadczeń, a tym samym zdobyć intelektualne narzędzia pozwalające zrozumieć charakter nowej fazy walk, trzeba skupić się na polączonych pojęciach rewolucji i dialektyki. Takie wlaśnie stanowisko zająl przed ponad wiekiem Wlodzimierz Lenin, widząc we wlaściwym opracowaniu tych pojęć gwarancje powodzenia rewolucyjnej praktyki. To w jego biografii jako dzialacza politycznego i teoretyka - splot rewolucji i dialektyki staje się widoczny szczególnie wyraźnie; stworzyl on bowiem przesłanki interwencji praktyczno-teoretycznej, która wyznaczyła logike dwudziestowiecznych walk robotniczych i kolonialnych. Bez względu więc na dalsze tragiczne losy rewolucji październikowej, zawile meandry polityki „międzynarodowego ruchu komunistycznego" czy intelektualne mielizny urzędowego „marksizmu-leninizmu”, Lenin pozostaje wciąż punktem odniesienia dla prób pomyślenia I urzeczywistnienia rewolucyjnego zerwania. Zwłaszcza w naszej dzisiejszej sytuacji - sytuacji historycznej kapitulacji znanych antykapitalistycznych alternatyw i jednocześnie zawiązywania się nowych walk, które czekaja nie tylko na swój Manifest komunistycrny, ale także na swoje Co robic? na swój Imperializm jako najnyzş̨e stadium kapitalirmu i na swoje Państwo i rensolucje. To Lenin byl tym myślicielem w historii ruchu robotniczego, który przeksztalcil dialektykę w narzędzie analizy związku między rozwojem sprzeczności globalnego, imperialnego kapitalizmu i charakterem toczonych przeciwko niemu walk, a także związku między charakterem tych walk $i$ ich polityczną organizacja. Te dwie perspektywy analizy musza stanowić dzisiaj dla nas niezbędny punkt wyjścia. Zdać sobie musimy sprawę, że z przedwcześnie ogłoszonego czasu posthistorycznego wydostaniemy się tylko wówczas, gdy odzyskamy slownik, pozwalający wyrazić pragnienie innego, wykraczającego poza kapitalizm 
porządku, oraz sformulować strategię tego wyjścia. Slownik ten nie może obyć się bez pojęć rewolucji i dialektyki.

Próba odczytania w tej perspektywie dokonań Lenina zderza się z oczywistymi trudnościami. Próżno byloby szukać ważnego dla tradycji radykalnej autora, który po 1989 roku zajmowalby równie marginalną pozycję w polskim dyskursie humanistycznym. Tak „gorliwie" studiowany i cytowany w pracach z niemal wszystkich możliwych dziedzin nauki w okresie PRL, po transformacji i restytucji kapitalizmu stal sie przedmiotem zainteresowania co najwyżej średnich lotów publicystyki lub szukających szwarccharakteru akademików. PRL-owskiej hagiografii nie powinna jednak zastępować, momentami niemniej karykaturalna, sowietologiczna demonizacja. Nasz (post)historyczny moment sprzyja raczej ponownej lekturze Lenina, która skupiając się na pojęciach rewolucji i dialektyki, omijalaby mielizny „lektury kamerdynerskiej” (jak ująlby to Marek Siemek) oraz slabości konserwatywnej wizji politycznego „wydarzenia”, rewolucji jako psychoanalitycznego aktu, o której mowa w Remolucï u bram Z̈ižka. Niniejszy numer traktować chcemy jako próbę wlaśnie tego rodzaju lektury.

Jej przyklady to otwierające numer teksty Bartosza Wójcika i Stathisa Kouvelakisa, które poświęcono zarówno filozoficznemu, jak i politycznemu znaczeniu studiów Lenina nad Nanka Logiki Hegla. Pytanie o to, dlaczego rosyjski rewolucjonista w chwili wybuchu I wojny światowej (i towarzyszącego jej załamania internacjonalizmu II Międzynarodówki) oddal się studiom dialektyki, do dziś stanowi przedmiot kontrowersji, a między proponowanymi interpretacjami zarysowuje się bardzo wyraźny konflikt. Kwestia ciagłości lub jej braku pomiędzy pierwsza „filozoficzną” rozprawą Lenina, a więc Materialiẓmem a empiriokrytycyzmem, i pisanymi już po lekturze Hegla Zesaytami filoæoficrnymi zajmowala takich autorów jak Louis Althusser, Henri Lefebvre, Lucio Colletti czy Raja Dunajewska. Debata ta, choć na pierwszy rzut oka może wydawać się czysto akademickim sporem, w rzeczywistości odnosi się do dwóch niezwykle istotnych kwestii politycznych. Po pierwsze, w zależności od odpowiedzi na powyższe pytanie utrwaleniu lub rozpadowi ulega istotny podzial na „marksizm zachodni” i „marksizm wschodni”, mający rzekomo stanowić teoretyczną podstawę rosyjskiego (a później środkowoeuropejskiego) modelu ,realnego socjalizmu”. Po drugie, debata ta stanowi punkt wyjścia dla prób odpowiedzi na pytanie o to, na ile wlaściwie dialektyka może służyć jako teoretyczna plaszczyzna rewolucji. Sam Lenin nie mial w tej kwestii żadnych watpliwości. Mając na myśli swych oponentów w ruchu socjalistycznym, dawnych luminarzy II Międzynarodówki, pisal:

\footnotetext{
Wszyscy oni nazywają siebie marksistami, pojmuja jednak marksizm do niemożliwości pedantycznie. Nie zrozumieli zupelnie tego, co w marksizmie jest decyduące, mianowicie: jego rewolucyjnej dialektyki. Absolutnie nie zrozumieli nawet wyraźnych wskazań Marksa, że w czasie rewolucji konieczna jest maksymalna elastyczność [...]
} 
znali dotychczas określona drogę rozwoju kapitalizmu i demokracji burżuazyjnej w Europie Zachodniej. I oto nie moga sobie wyobrazić, że ta droga może być uważana za wzór mutatis mutandis, to jest nie inaczej niż z pewnymi poprawkami [...] Na przykład nie przychodzi im nawet do glowy, że Rosja, znajdująca się na pograniczu krajów cywilizowanych i krajów po raz pierwszy przez tę wojnę ostatecznie wciagniętych w krag cywilizacji, krajów całego Wschodu, krajów pozaeuropejskich, że Rosja mogła i musiala wskutek tego przejawić pewne cechy swoiste (Lenin 1989, 370-371).

Przez wiele lat można było obserwować, jak wielu okcydentalnych filozofów i teoretyków marksizmu ustawialo swoisty kordon sanitarny wokól postaci Lenina, próbując tym samym zapewnić Zachodowi wylączność na krytyczne studia nad dialektyką. Odrzucając tę perspektywę, chcemy zaproponować takie interpretacje, które pozwalaja na odzyskanie emancypacyjnego i rewolucyjnego potencjalu dialektyki na peryferiach globalnego kapitalizmu. Stąd obok filozoficznych rozważań nad istotą Leninowskich studiów nad Heglowską dialektyka, chcemy podjać również problem zależności między rezultatami rewolucyjnie zorientowanej lektury Nauki logiki a perspektywami wymierzonej w imperializm i kolonializm polityki światowej. Kevin B. Anderson, kontynuując tradycje „marksizmu humanistycznego", w studium Odkryta na nowo i uporcsymie aktualna - o dialektyce w filozofii ipolityce śmiatowej przekonująco argumentuje, że za dostrzė̇eniem znaczenia ruchów narodowowyzwoleńczych dla polityki antyimperialistycznej przez Lenina stoi właśnie jego dogłębne zainteresowanie pismami Hegla. Perspektywę tę uzupelnia apendyks do głośnej książki Black Jacobins C.L.R. Jamesa, który zrywając z linearną koncepcją czasu historycznego na rzecz poszukiwania po leninowsku pojętych zrywów, skoków i dziejowych katastrof, śledzi losy tradycji emancypacyjnej na Karaibach - od Toussainta L'Ouverture'a po Fidela Castro.

Zapowiedzi przyszlego, pozbawionego ekonomicznego przymusu porzadku odnaleźć można nie tylko w pracach epigonów, lecz również u samego Lenina, nawet pomimo jego (typowej dla ówczesnych marksistów) niechęci do fantazjowania na temat socjalistycznej przyszlości. Florian Nowicki w artykule Samodyscyplina $i$ wszechstronnośc, w oparciu o uważną analizę rozproszonych tekstów Lenina z pierwszego porewolucyjnego okresu, podejmuje próbę zarysowania wizji „czlowieka komunistycznego”, podważając przy tym częste w literaturze wyobrażenia o Leninowskiej koncepcji „,rewolucji kulturalnej” i jednostkowym wymiarze rewolucyjnej transformacji, do której ostatecznie prowadzić miala walka klasowa. Pamiętać bowiem trzeba, że wlaśnie sam fenomen walki klas tkwil w sercu Leninowskiej interpretacji marksizmu. Lenin - co najlepiej być może widać wlaśnie, gdy rozważa on pojęcia rewolucji i dialektyki - nie byl marksistą „praw dziejowych” i historycznej konieczności, lecz przede wszystkim wnikliwym badaczem źródel i dynamiki klasowych 
antagonizmów społeczeństwa kapitalistycznego. Można więc widzieć w nim jednego z pierwszych metodologów analizy skladu klasowego, który podją próbę dostosowania politycznej organizacji proletariatu do caloksztaltu stosunków spolecznych. Tak też rolę Lenina interpretuje się często w obrębie tradycji operaistycznej. Antonio Negri - o czym pisze w prezentowanym numerze Michael Hardt - analizując drogę, którą przyszlo pokonać twórcom nurtu operaistycznego, stwierdza nawet, że „Lenin traktowany byl przez nas niemal jak metodologiczny esej” (Negri 2014, xx), stając się wręcz personifikacją określonej politycznej praktyki i metody. Zarysowana przez Hardta analizę recepcji Lenina we wloskim operaizmie przełomu lat sześćdziesiątych i siedemdziesiątych XX wieku uzupelnia tlumaczenie Lenina w Anglii Maria Trontiego. To tekst zalożycielski dla grupy operaistów skupionych wokól pisma Classe operaia, w którym wyartykulowana zostala, po raz pierwszy tak stanowczo, fundamentalna dla tej orientacji teza o „kopernikańskim zwrocie w marksizmie".

Prezentowany numer dopelniają artykuly recenzyjne, które uznać można za wstęp do krytycznych studiów historycznych nad Leninem i dwudziestowieczną tradycją rewolucyjną. W pierwszym z owych tekstów Piotr Kuligowski przygląda się uważnie biografii Lenina autorstwa Helen Rappaport, która podjęla próbę wyjścia poza monolityczne wyobrażenia o postaci rosyjskiego rewolucjonisty, skupiając się na emigracyjnym okresie jego życia. Damian Winczewski w swojej analizie esejów Johna Marota na temat rewolucji październikowej szkicuje $\mathrm{z}$ kolei najważniejsze linie przemian, jakim we wspólczesnej krytycznej historiografii ulegaja interpretacje rewolucji rosyjskiej. Przedstawia przy tym pozycje, z których wyprowadzane są skuteczne ataki na interpretacyjny duopol rządzący przez dekady tradycyjnymi ujęciami po obu stronach Żelaznej Kurtyny.

Rewolucja, dialektyka, komunizm, wyzwolenie, walka klas... wszystkie te słowa, jednocześnie polityczne hasła i niezwykle potężne idee teoretyczne, w 1917 roku przemienily się w materialne sily działające na scenie historii. Prawie sto lat później zakończyl swój żywot ostatni polityczny przywódca, którego do wladzy wyniosla potężna fala zrodzona z nadziei i entuzjazmu, jaki niosly ze sobą te slowa, przy jednoczesnym przejmowaniu wladzy w trybie demokratycznych wyborów przez faszyzujących polityków, którzy karmią się właśnie brakiem nadziei, cynizmem i marazmem. Co zrobić z tymi slowami - haslami, ideami i pojęciami dzisiaj? Zredukować je do postaci epitafium na grobie ostatniego z rewolucjonistów XX wieku? Czy może poddać je nowej interpretacji w przededniu kolejnych wstrząsów, kryzysów i demokratycznych zrywów? Czy w warunkach obecnej koniunktury historycznej, w dobie najnowszych walk spolecznych i coraz wyraźniej slyszalnych nawolywań do poszukiwania 
alternatyw dla kapitalizmu $\mathrm{w}$ slowa te wstapić może nowe życie? Czy mogą stać się skutecznymi narzędziami w oporze przeciwko nowym - a przy tym tak przerażająco znanym - formom faszyzmu? Z tego rodzaju pytań zrodzil sie pomysł na niniejszy numer. Wierzymy, że będa Wam one towarzyszyć w trakcie jego lektury. 


\section{Wykaz literatury}

Lenin, Wlodzimierz. 1989b. „O naszej rewolucji (W związku z notatkami N. Suchanowa)”. W Wlodzimierz Lenin, Drieta mszystkie, t. 47. Warszawa: Książka i Wiedza.

Negri, Antonio. 2014. Factory of Strategy. Thirty-three Lessons on Lenin. Thum. Arianna Bove.

New York: Columbia University Press.

CYTOWANIE: Praktyka Teoretyczna. 2016. Rewolucja i dialektyka - sto lat później. Praktyka Teoretyczna 2 (20). 9-15.

DOI: $10.14746 /$ prt.2016.2.0 